
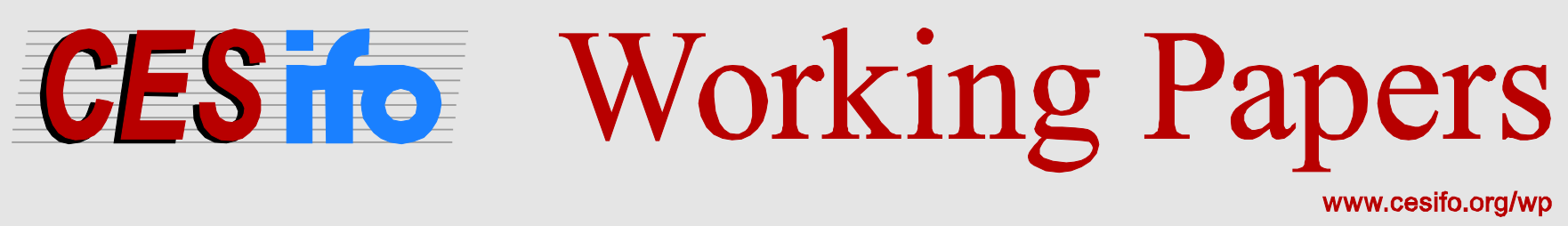

\title{
Stock Market Returns, Corporate Governance and Capital Market Equilibrium
}

\author{
Bruno M. Parigi \\ Loriana Pelizzon \\ Ernst-Ludwig von Thadden
}

\author{
CESIFO WORKING PAPER NO. 4496 \\ CATEGORY 7: MONETARY POLICY AND INTERNATIONAL FINANCE \\ NOVEMBER 2013
}

An electronic version of the paper may be downloaded

- from the SSRN website:

- from the RePEc website:

- from the CESifo website:

WWW.SSRN.com

www.RePEc.org

www.CESifo-group.org/wp

\section{CESifo}




\title{
Stock Market Returns, Corporate Governance and Capital Market Equilibrium
}

\begin{abstract}
This paper proposes a theoretical model that incorporates corporate governance into the basic CAPM, where corporate governance affects the disutility of managerial effort and the possibility of managers to divert company resources. It shows that corporate governance affects firms' stock returns and also how the quality of corporate governance is chosen endogenously. The model predicts that in equilibrium the quality of corporate governance correlates positively with $\beta$ and idiosyncratic volatility and negatively with returns on assets. Various tests with U.S. firm data using the corporate governance index of Gompers, Ishii, and Metrick (2003) confirm these predictions.
\end{abstract}

JEL-Code: G320, G380, K220.

Keywords: corporate governance, CAPM, variability of returns.

Bruno M. Parigi

University of Padova / Italy

brunomaria.parigi@unipd.it

Loriana Pelizzon

University Ca Foscari of Venice / Italy

pelizzon@unive.it
Ernst-Ludwig von Thadden

University of Mannheim / Germany

vthadden@uni-mannheim.de

November 18, 2013

We are grateful to Mike Burkart, Martijn Cremers, Xavier Giroud, Paul Laux, Ulf von Lilienfeld-Toal, Stew Myers, Matthew Rhodes-Kropf, Steven Ross, Antoinette Schoar, Per Stromberg, and seminar participants at the European Finance Association, Yale University, Temple University, MIT Sloan, Boston College, London Business School, University of Konstanz and the Stockholm School of Economics for useful discussions and Ludovic Calès and Andrea Lax for excellent research assistance. Pelizzon acknowledges the hospitality of the Department of Finance of the MIT Sloan where she was Visiting Associate Professor when this paper was developed. The usual disclaimer applies. 
Why should corporate governance matter for stock returns? After all, if a firm is run in a way such that managers or large shareholders can use company resources at the expense of outside shareholders, the firm's share price should adjust to reflect such conflicts of interest and the firm's stock returns should be unaffected. However, empirically, stock returns do seem to depend on corporate governance. ${ }^{1}$

The empirical literature that was initiated by Gompers, Ishii and Metrick (2003) has studied this problem by controlling stock returns for various factors and then relating abnormal returns $(\alpha)$ to measures of corporate governance quality. We address the problem from a new perspective, both theoretically and empirically, by looking at the two components of stock return volatility: systematic risk (measured by $\beta$ ) and idiosyncratic risk.

On the theory side, we model the optimal choice of corporate governance and show what determines the heterogeneity of governance provisions among companies and we provide a full-fledged equilibrium explanation of the relationship between the quality of corporate governance on the one hand and stock returns on the other. Empirically, we test these predictions and find strong support for them. From an empirical point of view, measurement errors are typically large for the estimation of average stock returns (and therefore of abnormal returns), while the estimation of stock return volatility needed for our $\beta$-theory is usually more accurate. Indeed, all our estimates are statistically highly significant. And interestingly, while the positive association between governance and abnormal returns identified by Gompers, Ishii and Metrick (2003) seems to disappear for the period 2000-2008 (Bebchuk, Cohen and Wang (2013)), our findings are empirically robust for the period 2000-2006.

Our theory starts out with the firms' cash flow fundamentals and embeds the singlefirm problem in a capital market in which investors behave according to a simple onefactor CAPM. Hence, we rule out excess returns by assumption. We then address the managerial effort problem that motivates the corporate governance restrictions in the first place, and show that this agency problem influences the firm's beta and idiosyncratic return volatility for any given level of managerial ownership. However, since in a model of capital market equilibrium, the manager must be allowed to trade in her firm's shares,

\footnotetext{
${ }^{1}$ See our literature discussion below.
} 
the manager's ownership stake becomes endogenous, which therefore provides a second incentive mechanism for managerial effort. The market prices the shares anticipating the effort that the owner-manager will exert given the governance choice and the inside equity she retains. This in turn can potentially blunt the role of corporate governance for managerial effort provision. In a final step we therefore endogenize the firm's governance choice and show that it plays an independent role next to inside equity. As a result, corporate governance, stock returns, beta, and managerial ownership are all endogenous, and we can predict their equilibrium correlations in response to variations of the model parameters.

The key to a conceptual understanding of the impact of corporate governance is the agency model of managerial behavior that underlies the corporate governance problem. We emphasize two related but independent features of corporate governance. On the one hand, lax governance allows managers to use company resources to their own advantage, typically at a loss to outside shareholders. On the other hand, strict corporate governance is counterproductive because managerial discretion improves initiative and flexibility, increases intrinsic motivation, and more generally, fosters managerial effort. There is a large literature on the complex problem of managerial effort provision in finance, microeconomics, and behavioral economics, too vast to be reviewed here. ${ }^{2}$

In a nutshell, we assume that strict corporate governance impedes managerial value creation, but prevents managers from diluting the value they create. The resulting tradeoff is at the heart of our governance problem, which we then embed in a standard CAPM.

To preview our theoretical results, we show, first, that the amount of private benefits extracted, the effort provided, and the amount of equity held by the owner-manager are fully priced in the value of the stock. However, the costs and benefits of corporate governance depend on individual firm characteristics, which implies that the strength of corporate governance varies among firms in equilibrium. The resulting comparative statics then show, second, that stricter corporate governance is associated with higher betas. Hence, the higher is the co-movement of a firm's cash flows with the market portfolio, the lower is the amount of cash flows that the manager will divert in equilibrium.

\footnotetext{
${ }^{2}$ See, in particular, Bebchuk and Weisbach (2010), Harris and Raviv (2010), Hellwig (2000), Shleifer and Vishny (1997), Vives (2000), and Zingales (2008) for excellent discussions of the costs and benefits of corporate governance.
} 
Third, the heterogeneity of governance structures is also linked to the idiosyncratic risk of cash flows, in the sense that higher idiosyncratic stock return volatility is associated with stricter corporate governance. Fourth, the model predicts a negative cross-sectional correlation between accounting measures of firm performance, such as return on assets, and the strength of corporate governance.

In Sections III and IV we test these three predictions on a sample of U.S. listed firms. Clearly, measuring the quality of corporate governance poses difficulties. One widely used measure of the (inverse of the) quality of corporate governance in the U.S. is the Gompers, Ishii, and Metrick (2003) Index of anti takeover provisions (GIM Index, see Appendix B). This index certainly misses a number of components of corporate governance, but its emphasis of corporate rules and provisions that protect management from outside interference captures a key element also of our model. We therefore use the GIM index as our (inverse) measure of corporate governance quality.

A test of the above implications must take into account that both in the model and in reality, the quality of the governance, the stock's $\beta$, and the stock's idiosyncratic volatility are all endogenous. After our uni- and multivariate regressions we thus resort to 2SLS estimation where in the first stage the GIM Index is instrumented with firm age. In the second stage, $\beta$ and idiosyncratic volatility are regressed separately against the fitted GIM Index along with controls. The results show negative and significant relations between the fitted GIM Index on the one hand and $\beta$ and idiosyncratic volatility on the other, as predicted by the theoretical model.

This paper is related to different strands of the literature. First it is related to the studies of the relation between corporate governance and asset pricing, most notably Gompers, Ishi, and Metrick (2003) and after them, Cremers and Nair (2004), Ferreira and Laux (2007), Bebchuk, Cohen, and Ferrell, (2009), Cremers, Nair, and John (2009), Johnson, Moorman and Sorescu (2009), Sautner and Villalonga (2011), and Acharya, Gottschalg, Hahn, and Kehoe (2011). Giannetti and Koskinen (2010) investigate the effect of investor protection on stock returns and portfolio allocations for cross-border portfolio investments, both theoretically and empirically. All these studies start with the observation that corporate governance is heterogenous among firms or among countries and investigate its implications for share prices or abnormal equity returns. None of these 
papers provides a theoretical model that endogenously determines corporate governance choice and none considers $\beta$ as a structural variable.

Second, this paper is also related to the literature on opacity and governance, as bad governance is usually associated with private information and little disclosure. In particular, our paper is related to Jin and Myers (2006) who show that lack of transparency drives the $\mathrm{R}^{2}$ of stock return higher in a cross-country regression. In their theory, stocks are affected by one market factor observable to everyone and two idiosyncratic factors, only one of which is observable also to outsiders. The fact that one factor is observable only to insiders (lack of transparency) allows them to extract benefits from the cash flows when they are high. This implies that less idiosyncratic risk is impounded into the stock price and thus that the $\mathrm{R}^{2}$ of stock returns is larger. Again, this paper does not consider the choice of the level of opacity/bad governance, but simply sets out from the observation that opacity/corporate governance is heterogenous across firms. Other important contributions to this literature are Easley and O'Hara (2004) who show that uninformed traders require compensation to hold stocks with greater private information, and Lambert, Leuz and Verrecchia (2009) who show that the quality of accounting information can influence the cost of capital in a CAPM framework.

Our work is complementary to this strand of literature as we provide a theoretical foundation for the choice of corporate governance rules and to its heterogeneity and we investigate the relationship between corporate governance and systematic and idiosyncratic stock returns volatility without considering the hypothesis of opacity.

The empirical paper closer to ours in this line of research is Ferreira and Laux (2007), who find at the U.S. company level that worse governance quality is associated with low transparency, which they proxy by idiosyncratic return volatility. ${ }^{3}$ On this front our results are qualitatively similar to those of Ferreira and Laux (2007): namely, a higher GIM Index is associated with higher opacity of stock returns, measured as idiosyncratic volatility over total volatility. We go beyond Ferreira and Laux (2007) by also considering systematic risk and by arguing that the observed governance-risk relation is the result of an equilibrium

\footnotetext{
${ }^{3} \mathrm{~A}$ related interpretation of idiosyncratic volatility is in terms of the availability of information: high levels of idiosyncratic volatility are associated with more efficient capital allocation (Durnev, Morck, and Yeung 2004) and with stock prices being more informative about future earnings (Durnev et al. 2003). Furthermore, lower levels of idiosyncratic volatility are found in emerging markets compared to developed markets (Morck, Yeung, and Yu 2000).
} 
tradeoff.

The rest of this paper is organized as follows. In Section I we construct our theoretical model of asset pricing that incorporates corporate governance choices in the CAPM. Section II derives our theoretical predictions. Section III describes the data. Section IV tests our theoretical predictions in various regression set ups, and Section V concludes. A longer proof and a detailed description of the GIM Index are provided in the Appendix.

\section{The Model: Description}

In this section, we present a simple structural model that generates testable hypotheses about the relationship between asset pricing and corporate governance. We do not take a stance on whether corporate governance drives asset returns or vice versa, and rather work with a model in which both are endogenous and driven by the same factors.

Consider a competitive capital market with representative firm $i$, run by a manager who initially owns all the shares. The model has three dates. At date 0 , the ownermanager decides about the quality of corporate governance of the firm. $g_{i}$ describes the laxity of corporate governance: the larger $g_{i}$ the less the owner-manager is monitored and the higher are managerial private benefits. Private benefits reduce the firm's cash flows by $h_{i} g_{i}$ with $h_{i}>0$, because benefit-taking disrupts the firm's operations or comes directly at the expense of shareholders' money. Managers and shareholders therefore have directly opposing interests over $g_{i} . g_{i}$ is a measure of corporate governance weakness and thus a theoretical counterpart to the GIM Index (Gompers, Ishii, and Metrick (2003), see Appendix B for a detailed description).

At date 1 the firm's shares are traded publicly at the competitive price $P_{i 1}$. The ownermanagers can trade shares at this price, provided that she discloses her final shareholding $\pi_{i}$.

At date 2 the owner-manager exerts a privately observed effort $e_{i}$ to increase cash flows, and then cash flows $C_{i}$ are realized. Managerial effort has a private cost, the monetary equivalent of which is

$$
\frac{e_{i}^{2}}{2 k_{i} g_{i}^{r}}
$$

where $r>0, k_{i}>0$. Hence, effort is less costly to the manager if she enjoys more dis- 
cretion. In other words, all else being equal, stricter corporate governance has a negative effect on managerial effort. This follows the "incentive approach" to corporate governance (Harris and Raviv, 2010) that emphasizes the potential costs of strict governance. Underlying these costs are the potentially discouraging effects of corporate governance, by restricting managerial initiative (Burkart, Gromb, Panunzi, 1997) or by crowding out intrinsic motivation by extrinsic motivation (Falk and Kosfeld, 2005). ${ }^{4}$ The alternative theory, that stricter corporate governance increases managerial effort by decreasing effort costs, corresponds to the case $r<0$ in (1). We shall later show that, in our model, this assumption would lead to predictions inconsistent with the data.

There is a safe asset with interest rate $R_{f}$ between between date 1 and date 2 . For simplicity, we assume that cash flows only accrue at the final date. The date- 2 cash flow of firm $i$ is assumed to be given by the standard one-market factor model

$$
C_{i}=A_{i}+\theta_{i} e_{i}+B_{i} R_{M}+\varepsilon_{i}
$$

where $R_{M}$ is the market return with expected return $\bar{R}_{M}$ and variance $\sigma_{M}^{2}, \varepsilon_{i}$ is random with mean 0 and variance $\sigma_{\varepsilon i}^{2}, \operatorname{cov}\left(\varepsilon_{i}, R_{M}\right)=0, A_{i}, B_{i}$ are constant, and $\theta_{i} \geq 0$ is the marginal impact of managerial effort on cash flow.

Stock market investors, who have mean-variance preferences over wealth at date 2 , have homogenous expectations at date 1 and therefore invest according to two-fund separation and price the firm's shares in line with the classical CAPM. Investors take the firm's corporate governance as given and correctly anticipate the owner-manager's effort choice and public cash flow of $C_{i}-h_{i} g_{i}$ at date 2. Thus corporate governance affects public cash flows at two stages: indirectly at the effort stage and directly at the stage of the extraction of managerial private benefits.

Hence, the owner-manager's final wealth consists of the public cash flow from her stake $\pi_{i}$ in her own firm, the monetary value of her private benefits, her holding of the market portfolio, and her cash from trading at date 1 . When selling the stake $1-\pi_{i}$ of her firm, the owner-manager realizes cash of $\left(1-\pi_{i}\right) P_{i 1}$, out of which she invests $m_{i} \geq 0$ in the market portfolio, whose price we normalize to 1, and keeps the rest in the risk-free asset.

\footnotetext{
${ }^{4}$ See the references in the introduction for broader discussions of the costs and benefits of corporate governance.
} 
Her final wealth therefore is

$$
W_{i}=\pi_{i}\left(C_{i}-h_{i} g_{i}\right)+\phi_{i} h_{i} g_{i}+m_{i}\left(1+R_{M}\right)+\left(\left(1-\pi_{i}\right) P_{i 1}-m_{i}\right)\left(1+R_{f}\right)
$$

where $\phi_{i} h_{i} g_{i}$ with $0 \leq \phi_{i}<1$ denotes the value of private benefits accruing from governance regime $g_{i} . \phi_{i}$ is exogenous and depends on manager's and firm characteristics such as its industry, as well as on aggregate factors such as the legal framework or the overall governance standards in the market.

Like all other investors, the owner-manager is risk-averse, with mean-variance utility

$$
U_{i}=E W_{i}-\frac{\lambda_{i}}{2} \operatorname{var}\left(W_{i}\right)-\frac{e_{i}^{2}}{2 k_{i} g_{i}^{r}}
$$

where $\lambda_{i}$ denotes the risk aversion of the owner-manager, and, using (2),

$$
\operatorname{var}\left(W_{i}\right)=\sigma_{M}^{2}\left(\pi_{i} B_{i}+m_{i}\right)^{2}+\pi_{i}^{2} \sigma_{\varepsilon i}^{2}
$$

Our results are driven by risk and managerial moral hazard. Risk and its impact are measured by the parameters $\lambda_{i}, B_{i}, \sigma_{M}^{2}$, and $\sigma_{\varepsilon i}^{2}$. The importance of managerial moral hazard can be measured by $1 / k_{i}$, the cost of providing effort, $\theta_{i}$, the effect of effort on cash flow, $h_{i}$, the cash flow loss from private benefit taking, and $\phi_{i}$, the ease with which private benefits can be appropriated. Obviously not all of these parameters will have an independent influence, and we will later normalize some of them.

\section{The Model: Results and Predictions}

We solve the model backwards, first determining the owner-manager's effort at date 2, then the share price at date 1 and the owner-manager's trading and portfolio decision $\left(\pi_{i}, m_{i}\right)$, and then the corporate governance structure $g_{i}$ at date 0 . Hence, the ownermanager determines $g_{i}$ knowing that she can later adjust her shareholdings, but that the stock price will change in response to her trade. 


\section{A Effort choice}

Since effort is additively separable in our model, inserting (2) into (4) yields the first-order condition for effort choice as

$$
\begin{aligned}
\pi_{i} \theta_{i}-\frac{1}{k_{i} g_{i}^{r}} e_{i} & =0 \Leftrightarrow \\
e_{i} & =\pi_{i} \theta_{i} k_{i} g_{i}^{r} .
\end{aligned}
$$

Thus effort is increasing in $\pi_{i}$ and in $g_{i}$. The positive effect of inside equity on effort is standard and well understood. The positive effect of $g_{i}$ on effort (i.e. the negative impact of strict corporate governance on effort) follows the incentive arguments discussed earlier, with the notion that close managerial monitoring stifles initiative and hence effort.

Inserting (6) into (3) yields

$W_{i}=\pi_{i}\left(A_{i}+B_{i} R_{M}+\varepsilon_{i}\right)+\pi_{i} \theta_{i}^{2} k_{i} g_{i}^{r}-\pi_{i} h_{i} g_{i}+\phi_{i} h_{i} g_{i}+\left(1-\pi_{i}\right) P_{i 1}\left(1+R_{f}\right)+m_{i}\left(R_{M}-R_{f}\right)$

This expression exhibits some of the effects of corporate governance on the ownermanager's wealth quite clearly. On the one hand, higher $g_{i}$ decreases wealth through the dilution of public cash flow (the term $-\pi_{i} h_{i} g_{i}$ ), which depends on the owner-manager's final ownership $\pi_{i}$. On the other hand, higher $g_{i}$ increases her wealth through, first, higher optimal effort (the term $+\pi_{i} \theta_{i}^{2} k_{i} g_{i}^{r}$ ) and second, through higher private benefits (the term $+\phi_{i} h_{i} g_{i}$ ). Of course, $W_{i}$ is also indirectly affected through $P_{i 1}$ and $m_{i}$. It turns out that the second of these direct benefits is not necessary to derive our results. We therefore let $\phi_{i}=0$ from now on to simplify the expressions. ${ }^{5}$

\section{B Capital market equilibrium}

Pricing at date 1 is a simple application of the CAPM. Recall that the value of the market portfolio at date 1 is normalized to 1 and the expected return on the market as of date 1 is $\bar{R}_{M}$. By the CAPM, $P_{i 1}$ adjusts such that the expected return of firm $i\left(E R_{i}\right)$ is

$$
E R_{i}=R_{f}+\beta_{i}\left(\bar{R}_{M}-R_{f}\right)
$$

\footnotetext{
${ }^{5}$ All our results hold with $\phi_{i}>0$.
} 
where $R_{i}=P_{i 2} / P_{i 1}-1$ is the holding-period rate of return of firm $i$ 's shares, and

$$
\beta_{i}=\frac{\operatorname{cov}\left(R_{i}, R_{M}\right)}{\operatorname{var}\left(R_{M}\right)}
$$

Substituting for $R_{i}$ into the CAPM formula (8) yields

$$
\frac{E P_{i 2}}{P_{i 1}}-1=R_{f}+\frac{\operatorname{cov}\left(R_{i}, R_{M}\right)}{\operatorname{var}\left(R_{M}\right)}\left(\bar{R}_{M}-R_{f}\right)
$$

By (2),

$$
P_{i 2}=C_{i}-h_{i} g_{i}=A_{i}+\theta_{i} e_{i}+B_{i} R_{M}-h_{i} g_{i}+\varepsilon_{i}
$$

which implies

$$
\begin{aligned}
\operatorname{cov}\left(R_{i}, R_{M}\right) & =\operatorname{cov}\left(\frac{P_{i 2}-P_{i 1}}{P_{i 1}}, R_{M}\right) \\
& =\frac{B_{i}}{P_{i 1}} \sigma_{M}^{2}
\end{aligned}
$$

From (10), the expected rate of return of stock $i$ therefore is

$$
E \frac{P_{i 2}}{P_{i 1}}-1=R_{f}+\frac{B_{i}}{P_{i 1}}\left(\bar{R}_{M}-R_{f}\right)
$$

Substituting for $P_{i 2}$ in (13) from (11) yields $P_{i 1}$, firm's $i$ date-1 market value:

$$
\begin{aligned}
& A_{i}+B_{i} \bar{R}_{M}+\theta_{i} e_{i}-h_{i} g_{i}=\left(1+R_{f}\right) P_{i 1}+B_{i}\left(\bar{R}_{M}-R_{f}\right) \\
\Rightarrow & P_{i 1}=\frac{1}{1+R_{f}}\left(A_{i}+R_{f} B_{i}+\theta_{i} e_{i}-h_{i} g_{i}\right)
\end{aligned}
$$

where we assume that $h_{i}$ is small enough that $P_{i 1}>0$.

Combining (14) with (11) yields

$$
\begin{aligned}
R_{i} & =\frac{P_{2}}{P_{1}}-1 \\
& =R_{f}+\frac{\left(1+R_{f}\right) B_{i}}{F_{i}+\theta_{i} e_{i}-h_{i} g_{i}}\left(R_{M}-R_{f}\right)+\frac{1+R_{f}}{F_{i}+\theta_{i} e_{i}-h_{i} g_{i}} \varepsilon_{i}
\end{aligned}
$$

where $F_{i}=A_{i}+B_{i} R_{f}$. Equation (15) describes the classic linear regression of firm returns 
on the market return. In this regression, the observed beta is given by

$$
\beta_{i}=\frac{B_{i}\left(1+R_{f}\right)}{F_{i}+\theta_{i} e_{i}-h_{i} g_{i}}
$$

Writing the idiosyncratic return component in (15) as

$$
\eta_{i}=\frac{1+R_{f}}{F_{i}+\theta_{i} e_{i}-h_{i} g_{i}} \varepsilon_{i}
$$

one can re-write (15) in the standard form

$$
R_{i}=R_{f}+\beta_{i}\left(R_{M}-R_{f}\right)+\eta_{i}
$$

which is the stochastic version of the expected-return CAPM equation (8), where the standard deviation of idiosyncratic returns in (17) is

$$
\sigma_{\eta i}=\frac{1+R_{f}}{F_{i}+\theta_{i} e_{i}-h_{i} g_{i}} \sigma_{\varepsilon i}
$$

Therefore, in a competitive market where stock prices are determined according to the CAPM, the amount of private benefits extracted by the insiders is fully priced in the value of the stock. Hence, corporate governance does affect expected returns, and it does so via the risk component given by $\beta$. In fact, the partial equilibrium solution (16) has the same logic as that of the levered beta in Hamada (1972) and other applications of Modigliani and Miller's (1958) Proposition 2, because $g_{i}$ represents a state-independent deduction from cash flows. But this is only the partial-equilibrium view. Since $g_{i}$ influences $e_{i}$, the effect of $g_{i}$ on $\beta_{i}$ is, in fact, U-shaped, if ownership $\pi_{i}$ is assumed constant, as can been seen from substituting $e_{i}$ into $\beta_{i}$. But that is not the full story either, because $\pi_{i}$ and $g_{i}$ are endogenous, as well, as we discuss presently.

\section{Ownership and portfolio choice}

When the owner-manager makes her ownership and portfolio choice, the market takes the corporate governance choice $g_{i}$ as given, correctly anticipates the induced value of effort, and sets the stock price consistent with managerial ownership. Hence, managerial ownership $\pi_{i}$, the owner-manager's portfolio choice $m_{i}$, and the stock price $P_{i 1}$ in (14) are 
determined simultaneously.

Using the optimal effort (6), and inserting $P_{i 1}$ from (14) into (4) yields the owner's objective function at the stage when she determines her final ownership position $\pi_{i}$ and her market exposure $m_{i}$ at date 1 :

$$
\begin{aligned}
U_{i}= & F_{i}+\pi_{i} \theta_{i}^{2} k_{i} g_{i}^{r}-\frac{1}{2} \pi_{i}^{2} \theta_{i}^{2} k_{i} g_{i}^{r}-h_{i} g_{i}+\left(\pi_{i} B_{i}+m_{i}\right)\left(\bar{R}_{M}-R_{f}\right) \\
& -\frac{\lambda_{i}}{2}\left[\sigma_{M}^{2}\left(\pi_{i} B_{i}+m_{i}\right)^{2}+\pi_{i}^{2} \sigma_{\varepsilon i}^{2}\right] .
\end{aligned}
$$

For simplicity, we ignore the short-selling constraints $0 \leq \pi_{i} \leq 1$ and $0 \leq m_{i} \leq\left(1-\pi_{i}\right) P_{i 1}$, which will be satisfied at the unconstrained optimum, as can be easily checked.

Differentiating (20) with respect to $m_{i}$ and $\pi_{i}$ yields straightforward first-order conditions, which we summarize in the following lemma.

Lemma 1 For any given governance choice $g_{i}$, the optimal ownership and portfolio choices are

$$
\begin{aligned}
\pi_{i}^{*} & =\frac{t_{i} g_{i}^{r}}{L_{i}+t_{i} g_{i}^{r}} \\
m_{i}^{*} & =\frac{\bar{R}_{M}-R_{f}}{\lambda_{i} \sigma_{M}^{2}}-\frac{B_{i} t_{i} g_{i}^{r}}{L_{i}+t_{i} g_{i}^{r}}
\end{aligned}
$$

where $t_{i}=\theta_{i}^{2} k_{i}$ and $L_{i}=\lambda_{i} \sigma_{\varepsilon i}^{2}$, to simplify notation.

It is straightforward to verify that the first-order conditions indeed yield an optimum. Interestingly, from the perspective of the owner in (20), her cash flow cost of lax governance does not depend on her ownership stake $\pi_{i}$, although a priori she bears the dilution of cash flows only in proportion to her ownership stake (the third term in (7)). This is because the market prices the dilution fully, which makes the owner bear the full cost of weak governance through the price $P_{i 1}$ regardless of the ownership stake she decides to hold.

Hence, the optimal ownership stake trades off effort incentives against risk sharing. The direct benefit and cost of effort are given by the second and third term of (20), respectively, while terms 5 and 6 represent the traditional risk-return tradeoff. Note that if the latter concern were absent, i.e. if $L_{i}=0$ (no risk or no risk aversion), then $\pi_{i}=1$ and the owner would not sell out at all, just as in traditional theory. Only if risk matters does ownership matter, and this is influenced by the incentive effects of corporate governance. 
In fact, varying $g_{i}$ as an exogenous parameter, Lemma 1 yields the following comparative statics.

Lemma 2 Optimal managerial ownership $\pi_{i}^{*}$ and optimal managerial effort

$$
e_{i}^{*}=\frac{1}{\theta_{i}} \frac{t_{i}^{2}}{L_{i}+t_{i} g_{i}^{r}} g_{i}^{2 r}
$$

are increasing in $g_{i}$.

Hence, taking $g_{i}$ as an exogenous parameter, stricter corporate governance makes the manager exert less effort and reduces her ownership stake. The reason is that, by (6), governance weakness and ownership are strategic complements for effort provision, with positive direct effects on managerial effort. Since the negative cash flow effect of weak corporate governance is independent of ownership by rational expectations in stock market trading, increasing governance weakness $g_{i}$ only increases the marginal incentive effect of ownership. Hence, the direct effect of $g_{i}$ on effort and the indirect effect via $\pi_{i}$ both go in the same direction.

\section{Governance choice}

Lemma 2 has examined exogenous changes of $g_{i}$. We now investigate the equilibrium choice of $g_{i}$. Inserting (21) and (22) in (20) yields

$$
U_{i}^{*}=F_{i}+\frac{1}{2} \frac{t_{i}^{2} g_{i}^{2 r}}{L_{i}+t_{i} g_{i}^{r}}-h_{i} g_{i}+\frac{\left(\bar{R}_{M}-R_{f}\right)^{2}}{2 \lambda_{i} \sigma_{M}^{2}} .
$$

The following derivatives are straightforward to obtain and useful to note:

$$
\begin{aligned}
\frac{d U_{i}^{*}}{d g_{i}} & =\frac{r t_{i}^{2}}{2} \frac{g_{i}^{2 r-1}}{\left(L_{i}+t_{i} g_{i}^{r}\right)^{2}}\left(2 L_{i}+t_{i} g_{i}^{r}\right)-h_{i} \\
\frac{d^{2} U_{i}^{*}}{d g_{i}^{2}} & =-\frac{r t_{i}^{2} g_{i}^{2 r-2}}{2\left(L_{i}+t_{i} g_{i}^{r}\right)^{3}}\left[2(1-2 r) L_{i}^{2}+3(1-r) t_{i} L_{i} g_{i}^{r}+(1-r) t_{i}^{2} g_{i}^{2 r}\right] .
\end{aligned}
$$

An inspection of $(25)$ and (26) shows that $U_{i}^{*}$ has a unique, strictly positive maximum if $r \leq 1 / 2$, i.e. if the positive incentive effect of weak governance is not too strong. In 
order to get testable predictions we therefore impose this restriction from now on. ${ }^{6}$ With this assumption, (25) therefore implies:

Proposition 3 The optimal corporate governance decision is unique, satisfies $g_{i}^{*}>0$, and is given by

$$
r t_{i}^{2}\left(2 L_{i}+t_{i} g_{i}^{r}\right)=2 h_{i}\left(L_{i}+t_{i} g_{i}^{r}\right)^{2} g_{i}^{1-2 r}
$$

Proposition 3 trades off the direct and the indirect costs and benefits of stricter governance that we have discussed earlier. Remember that laxer governance creates value for all shareholders through the managerial incentive effect in (1). Hence, the owner-manager generally will not adopt the most stringent governance rules (i.e. $g_{i}^{*}=0$ ), precisely because the capital market fully prices the impact that governance has on effort, on inside equity and on public cash flows. Without the positive incentive effect of lax corporate governance (i.e. for $r<0$ ), corporate governance would be uniformly chosen as strictly as possible, with no cross-sectional variation. This is inconsistent with the data that we present in the next section.

To put this differently, corporate governance only matters if there is a real managerial moral-hazard problem. If the agent who makes the governance choices contributes nothing to cash flows $\left(\theta_{i}=0\right.$ or $\left.k_{i} \rightarrow 0\right)$, then she optimally chooses the strictest possible governance rules and zero ownership of the company. Otherwise, she would pay the cost of weak governance without any benefit in terms of additional cash flows. More formally, (24) implies

Corollary 4 If effort played no role, either because $k_{i} \rightarrow 0$ or because $\theta_{i}=0$, then $t_{i}=0$, $g_{i}^{*}=0$ and $\pi_{i}^{*}=0$.

\section{E Testable Propositions}

In our model, neither does corporate governance have a causal effect on stock prices, nor is the opposite true. Instead, governance $g_{i}$ and ownership $\pi_{i}$ on the one hand, and returns

\footnotetext{
${ }^{6}(25)$ and (26) show that the condition $r \leq 1 / 2$ is clearly not necessary. Depending on the size of the other parameters, weaker conditions on $r$ yield the same result. But the condition is simple and suffices to make the point. If weak governance has large positive incentive effects that outweigh its costs considerably, then there may be no maximum and governance is as lax as possible.
} 
$R_{i}$, idiosyncratic risk $\sigma_{\eta i}^{2}$ and observed $\beta_{i}$ on the other hand, are endogenous, driven by the same set of exogenous parameters. The uniqueness established in Proposition 3 implies that the equilibrium relation between the endogenous variables can be obtained by implicitly differentiating the first-order condition (27) and using the equilibrium expressions for $\beta_{i}$ and $\sigma_{\eta i}^{2}$.

Proposition 5 When the parameters $L_{i}, h_{i}$, and $t_{i}$ change, the equilibrium values of $\beta_{i}$ and $\sigma_{\eta i}^{2}$ move in the same direction, and opposite to that of the governance variable $g_{i}^{*}$. The detailed prediction is as follows:

$$
\begin{array}{llll} 
& g_{i}^{*} & \beta_{i} & \sigma_{\eta i}^{2} \\
L_{i}=\lambda_{i} \sigma_{\varepsilon i}^{2} & - & + & + \\
h_{i} & - & + & + \\
t_{i}=\theta_{i}^{2} k_{i} & + & - & -
\end{array}
$$

Given our simple one-factor model, it is clear that $\beta_{i}$ and $\sigma_{\eta i}$ comove positively, because from (16) and (19) we have

$$
\sigma_{\eta i}=\frac{\beta_{i}}{B_{i}} \sigma_{\varepsilon i}
$$

Our approach of modelling stock returns by going back to the cash flow fundamentals makes it possible also to look at operating performance. In our model, this variable is best described by final cash flow $C_{i}-h_{i} g_{i}$.

Proposition 6 When the parameters $L_{i}, h_{i}$, and $t_{i}$ change, the equilibrium values of the governance variable $g_{i}^{*}$ and of final cash flow, $C_{i}-h_{i} g_{i}$ move in the same direction. The detailed correlation is as follows:

$$
\begin{array}{ll} 
& C_{i}-h_{i} g_{i} \\
L_{i}=\lambda_{i} \sigma_{\varepsilon i}^{2} & - \\
h_{i} \quad & - \\
t_{i}=\theta_{i}^{2} k_{i} & +
\end{array}
$$

The predictions of Propositions 5 and 6 are the subject of the empirical tests that we conduct in the following section. Our main emphasis will be on the relationship between stock return characteristics and corporate governance (Proposition 5). We will not consider 
predictions about managerial ownership, simply because we do not have the data even if our model predicts similar relationship as those of final cash flow.

\section{The Data}

As noted in the introduction, measuring corporate governance quality poses serious difficulties. The GIM Index is probably the best available measure and widely used in the literature.

The GIM Index includes 24 anti-takeover provisions such as the existence of a staggered board, poison pill, supermajority voting requirement, limits to amend bylaws, limits to amend charters, golden parachute, etc. A full description is given in Appendix B. The GIM Index therefore describes how much management is protected from outside interference and provides a plausible proxy for our $g_{i}$ variable. We have re-scaled the 19 values of the GIM Index into 6 values to improve statistical power (a robustness check with the original 19 values is discussed later on). The mapping is as follows: values $(1,2,3)$ of the GIM Index become $0 ;(4,5,6) \rightarrow 1 ;(7,8,9) \rightarrow 2 ;(10,11,12) \rightarrow 3 ;(13,14,15) \rightarrow 4 ;(16,17,18,19) \rightarrow 5 . \quad 0$ is the best governance, 5 is the worse. The GIM Index is the IRRC (Investor Responsibility Research Center) governance index, as used in Gompers, Ishii and Metrick (2003), and is available for 4.016 U.S. firms covering more than $93 \%$ of the total capitalization of the NYSE, AMEX and NASDAQ ${ }^{7}$. The available years are 1990, 1993, 1995, 1998, 2000, 2002, 2004 and 2006 for an average of 1.750 firms per year. We linearly interpolated the GIM Index for missing years. Our sample period is therefore longer than the period in Gompers, Ishii, and Metrick (2003), which allows us to address the objection by Bebchuk, Cohen, and Wang (2013) that the observed correlation between the GIM Index and abnormal stock returns disappears after 2000 .

In Figure 1 we show the distribution of the observations by GIM Index without interpolation for the missing years.

\section{INSERT Figure 1 HERE}

\footnotetext{
${ }^{7}$ The GIM Index is available on Andrew Metrick's web page and in the WRDS database collected by IRRC (Investor Responsibility Research Center) and provided to WRDS by Institutional Shareholder Service (ISS) and RiskMetrix.
} 
Figure 1 presents a visual summary of the frequency distribution of the GIM Index values. In line with the prediction of proposition 3 , the governance choice is not zero in the large majority of cases. Hence, most firms do not choose the strictest possible governance rules. Instead the maximum frequency of GIM Index values is at the centre of the distribution, suggesting that the governance choice is the result of a trade-off.

Furthermore, we observe no major change in the GIM Index over time. Table I presents a transition matrix showing the number of changes in the GIM Index for consecutive periods over the sample. When a change occurs it is most likely a worsening of the GIM Index.

\section{INSERT Table I HERE}

Hence, most of the variation in the governance data is cross-sectional and not dynamic.

For each stock $i$ and each year we regress the stock's daily returns using the specification (15) with effort at its equilibrium level. Stocks return data are from the Center for Research in Stock Prices (CRSP), all other variables that we use as controls are from S\&P Compustat (see Table II for the definitions and sources of variables). This regression yields $R_{i}-R_{f}$, the yearly excess return of asset $i, \beta_{i}$, the yearly beta of asset $i, \sigma_{M}^{2}$, the variance of the yearly returns of the market portfolio, the latter being defined as the value weighted index of stocks in our dataset, and $\operatorname{sqrtV} R_{i}=\sqrt{\frac{\sigma_{\eta_{i, t}}^{2}}{\sigma_{M}^{2}}}$, the yearly normalized idiosyncratic volatility of asset $i$.

\section{INSERT Table II HERE}

As the GIM Index, the $\beta$ 's of the companies in our sample are rather stable over time: the average standard deviation of each company $\beta$ (computed over time) is 0.35 and the standard deviation of the cross section of the standard deviation of each company's $\beta$ is 0.19. Only 20 companies (out of the 2,876 with more than a single $\beta$ observation) have a standard deviation of their $\beta$ higher than 1 . 


\section{Empirical Results}

\section{A Quality of governance, idiosyncratic volatility, and $\beta_{i}$}

\section{A.1 Univariate analysis}

In Table III we present the $\beta_{i}$, normalized idiosyncratic volatility, and other firm's characteristics ordered by the governance index. We winsorize extreme observations at the bottom and top $1 \%$ levels to avoid spurious inferences. Companies with better governance (GIM Index $0,1,2$ ) have a higher $\beta_{i}$ and higher idiosyncratic volatility than companies with worse governance (GIM Index 3,4,5), and the differences are statistically significant. These results are in line with Proposition 5. In the same table we present the descriptive statistics of the other explanatory variables.

\section{INSERT Table III HERE}

The binary correlations (Table IV) show that the relationship between the GIM Index and $\beta_{i}$ is negative and significant, that between the GIM Index and $s q r t V R_{i}$ is negative and significant, and that between $\operatorname{sqrtV} R_{i}$ and $\beta_{i}$ is positive and significant. Hence, the unconditional correlation analysis supports our empirical predictions.

\section{INSERT Table IV HERE}

Table IV is also informative about the prediction of Proposition 6. Since assets are constant in our model but typically change in reality, final cash flow, $C_{i}-h_{i} g_{i}$ can best be approximated by Return on Assets (income divided by book total assets). Table IV indicates that, in line with our predictions, ROA is positively and significantly related to the GIM Index and negatively and significantly correlated with beta and idiosyncratic risk.

\section{A.2 Multivariate analysis}

The previous univariate analysis has exhibited the negative relationship between laxity in corporate governance, beta, and idiosyncratic risk predicted by Proposition 5. However, 
these results could be driven by other factors that are only incidentally correlated with governance. In fact, our theoretical model has highlighted that the relationships we have identified are hard to investigate empirically because there are factors that influence $g_{i}$ and may directly affect idiosyncratic risk and beta (such as $\sigma_{\varepsilon i}^{2}$ ). As usual, endogeneity issues and potentially omitted variables may prevent simple panel regressions from identifying the relation between corporate governance and stock return variables correctly.

We address the potential econometric problem in three different ways. First, we make use of an extensive number of control variables to reduce the possibility that corporate governance is related to idiosyncratic volatility or beta just because of omitted variables. Second, usually in panel regressions the residuals may be correlated across firms or across time, and OLS standard errors can be biased (see Petersen, 2008). Only clustered standard errors are unbiased as they account for the residual dependence created by the firm effect. We therefore estimate robust standard errors considering cluster effects. Third, we use instrumental variables. The identification of appropriate instruments is not trivial in our set up. A valid instrument should be exogenous and, in particular, should not be influenced by idiosyncratic risk and the beta of stock returns. Furthermore, it should be strongly correlated with the corporate governance variable and it should influence the dependent variable (in our case, idiosyncratic volatility and beta) only through its effect on the corporate governance variable and not directly.

In order to address this problem we use two-stage least squares. More formally, we model corporate governance in a reduced form equation as follows:

$$
g_{i, t}=a+a_{j} D_{j}+a_{t} D_{t}+\underline{\phi_{1}} \underline{X_{1}}+\underline{\phi_{2}} \underline{X_{2}}+\varepsilon_{i, t}
$$

where $\underline{X_{1}}$ and $\underline{X_{2}}$ are two sets of exogenous variables; $\varepsilon_{i, t}$ is the error term, $a$ the constant, $D_{j}$ are industry dummies, $D_{t}$ are time dummies, $a_{j}, a_{t}$ are dummy coefficients, and $\underline{\phi_{1}}$ and $\underline{\phi_{2}}$ are vectors of coefficients.

From the first-stage regression represented by Equation (28) we determine the fitted value $\widehat{g}_{i, t}$ that we use in the second-stage regression for the idiosyncratic risk and betas as

$$
\begin{aligned}
\sigma_{\eta_{i, t}} & =b+b_{j} D_{j}+b_{t} D_{t}+\beta_{1} \widehat{g}_{i, t}+\underline{\theta_{1} X_{1}}+\nu_{i, t}, \\
\beta_{i, t} & =c+c_{j} D_{j}+c_{t} D_{t}+\gamma_{1} \widehat{g}_{i, t}+\underline{\vartheta_{1} X_{1}}+v_{i, t},
\end{aligned}
$$


where $\nu_{i, t}$ and $v_{i, t}$ are the error terms, $b$ and $c$ are constants, $b_{j}, c_{j}, b_{t}, c_{t}, \beta_{1}$, and $\gamma_{1}$ are coefficients, and $\underline{\theta_{1}}$ and $\underline{\vartheta_{1}}$ are vectors of coefficients. We use the exogenous variables $\underline{X_{2}}$ only in equation (28) where they serve as instruments for the corporate governance variable. The endogeneity in the model can arise from potential correlations of the corporate governance variable and the error terms $\nu_{i, t}$, and $v_{i, t}$ in equation (29). We perform the Kleibergen-Paap test in order to determine the goodness of the instrument used.

The explanatory variable included in $\underline{X_{2}}$ as instrumental variable is the log of age (LNAGE). This variable does not seem to be directly related to betas or idiosyncratic risk, but is statistically highly related to the level of corporate governance as the KleibergenPaap test on endogeneity shows.

We consider a number of controls: market value, price to book value, Return on Assets, leverage, firm age, sectorial dummies and year dummies.

Table $\mathrm{V}$ reports the first and second-stage panel estimation and it shows that the relation between betas and idiosyncratic risk and corporate governance is in line with our theoretical predictions. Indeed, beta is negatively related to the instrumented values of corporate governance. The coefficient is -0.21 and is statistically significant at the $1 \%$ level. We obtain the same results for idiosyncratic risk: $s q r t V R_{i}$ is negatively related to the instrumented values of corporate governance. The coefficient is -0.56 and is statistically significant at the $1 \%$ level.

The tests for endogeneity does not allow us to reject the hypothesis that our instrument is exogenous: the Kleibergen-Paap test for underidentification rejects the null hypothesis that the instruments are underidentified. Moreover, we also report the Kleibergen-Paap Wald F-statistic that rejects the null hypothesis that the instrument does not enter the first stage regression. According to Bound et. al (1995), "F statistics close to 1 should be cause of concern". We have a $\mathrm{F}$ statistic of 148.64, suggesting that our regression is unlikely to be affected by a weak instrument. Moreover, since we are using only one instrument we have no problem of overidentification. Hence, the coefficient estimates are both consistent and efficient.

\section{INSERT Table V HERE}

In summary, our multivariate analysis corroborates the univariate results and is in line 
with the theoretical prediction of Proposition 5. First, the square root of the idiosyncratic volatility $\operatorname{sqr} V R_{i}$ is negatively and significantly correlated with the GIM Index. This confirms the finding by Ferreira and Laux (2007). Second, $\beta_{i}$ is negatively related with the GIM Index. This finding is new and potentially important, because it highlights a relevant and mostly ignored issue: private benefits are not only endogenous but the underlying corporate governance problem affects the firm's systematic risk. Our model shows that competition fails to eliminate private benefits as there is a trade off between weaker governance and managerial effort. In equilibrium, the controlling shareholder of an asset with a lower beta extracts more private benefits. But since private benefits are fully priced, this is fine for outside investors. However, even though the amount of private benefits extracted by the insiders is fully priced in the value of the stock, corporate governance does affect average returns via the risk component given by $\beta$.

\section{B Robustness and further analysis}

We test the robustness of our results with respect to different model specifications and different regressions methodologies. All the results reported in this subsection are available on request.

First, two-stage regressions with the GIM Index scaled from 1 to 19 yield similar results.

Second, we investigate whether the positive association between good governance and risk disappears in the more recent part of the sample. The issue of a sample break has been raised by Bebchuk, Cohen, and Wang (2013) in the traditional framework of estimating abnormal returns. They have shown that the findings of Gompers et al. (2003) largely vanish for the period 2000-2008 and attribute this to learning by market participants. We have performed eight cross-sectional regressions for the different years when the GIM Index is available $(1990,1993,1995,1998,2000,2002,2004$, and 2006) and find that the instrumented GIM Index is always negatively related to beta and idiosyncratic risk as predicted by our theory, and that the coefficients are at least significant at the $5 \%$ level. Hence, our findings hold over the entire period. The result is confirmed if we perform the two-stage regression of beta and idiosyncratic risk variables with respect to the instrumented GIM Index for the period 2000-2006. This shows that our findings are 
mainly due to a cross sectional effect rather than a time series effect, in line with our modelling approach.

Third, we conduct a two-stage regression of beta and idiosyncratic risk variables with respect to the lagged instrumented GIM Index to rule out possible reverse causality between the GIM Index and these factors, even if we do not take a stance on whether corporate governance drives asset returns or vice versa. We find the lagged instrumented GIM Index to be significant and to have the same sign as their non-lagged counterparts.

Fourth, we investigate whether the positive association between good governance and risk is associated only with a subset of the twenty-four governance provisions of the GIM Index. This issue has been raised by Bebchuk, Cohen, and Ferrell, (2009), who shows that only six provisions are associated with economically significant reductions of firm valuation and abnormal negative returns. We have performed the two-stage regression of beta and idiosyncratic risk variables with respect to the instrumented Entrechment Index based on the six provision identified by Bebchuk, Cohen, and Ferrell (2009) and find that the instrumented Entrechment Index is always negatively and significantly related to beta and the idiosyncratic risk as predicted by our theory. We repeated the analysis for the index based on the other eighteen provisions and the results are confirmed. Hence, our findings hold over subsets of the twenty-four governance provisions of the GIM Index.

In line with the work of Ferreira and Laux (2007) and the work of Cella, Ellul and Giannetti (2013) that shows that institutional investor ownership matters in amplifying the effect of shocks on stock returns, we have also considered institutional ownership as a control variable Our results are qualitatively similar to those in Table V.

We also investigate other instrumental variables and in particular the variable dividend yield (DY). This variable is statistically highly related to the level of corporate governance but does not seem to be directly related to betas or idiosyncratic risk, as the KleibergenPaap test on endogeneity shows. The results are reported in Table VI and are qualitatively similar to those reported in Table V where Age is the instrumental variable. However, on a priori grounds Age seems to be less subject to managerial manipulation and therefore more suitable as an instrument than DY.

\section{INSERT Table VI HERE}


Returning to the prediction of Proposition 6 regarding the relationship between public cash flows $C_{i}-h_{i} g_{i}$ and corporate governance, in our two-stage regression analysis ROA is not significantly related to the GIM Index from the first stage anymore (see Table V). ${ }^{8}$ This could be due to the fact that other control variables related to ROA reduce its explanatory power. However, ROA is still negatively and significantly correlated with beta and idiosyncratic risk in line with our theoretical predictions in the second stage. Again, to our knowledge ours is the first analysis with a theoretical and empirical relationship between beta (i.e. systematic) and idiosyncratic stock return risk on the one hand and return on assets on the other.

Our model can also provide predictions about the relationship between managerial ownership and corporate governance. However, empirical statements involving managerial ownership are difficult in general because of data problems. U.S. ownership data (which are still the best internationally) vary across different databases, have several biases, and are not always consistent (see Anderson and Lee, 1997, Dlugosz, Fahlenbrach, Gompers, and Metrick, 2006, and von Lilienfeld-Toal and Ruenzi, 2012). The available database provided by IRRC has the drawback that for more than $70 \%$ of the companies considered in our sample ownership is not available because it is below 5\%. For the remaining $30 \%$ managerial ownership is largely negatively related to firm size. If we combine ownership with the market value of the company to characterize the portfolio investment of the owner and perform our two-step analysis on the restricted sample where ownership is reported, we find that the GIM Index is positively and significantly related to ownership in line with the theoretical analysis (which we have not reported). However, the data are incomplete as noted, and more research would be needed to corrobate this point.

\section{Conclusion}

To conclude, this paper is motivated by the attempt to investigate why corporate governance choices matter for stock returns if the stock market understands and discounts the managerial agency problem correctly. To address this question we have constructed

\footnotetext{
${ }^{8}$ This result is in line with Gompers, Ishii and Metrick (2003). They find that the return on equity (income divided by book equity) is not significantly related with the GIM-index, in some years with a positive coefficient and in some others with a negative coefficient. We prefer to consider the Return on Assets rather then the Return on Equity because we would like to avoid that our results are affected by leverage.
} 
a model that incorporates two key elements of the managerial agency problem into the CAPM, with counterveiling effects of strict corporate governance. On the one hand, corporate governance affects the amount of private benefits a manager can enjoy, on the other it affects the disutility of effort in providing flexibility and initiative in managerial decision making. The tradeoff between these two motives yields an optimal degree of strictness of corporate governance.

The governance choice affects cash flows and through cash flows affect the firm's $\beta$ and idiosyncratic risk. Interestingly, the partial equilibrium effect, excluding the optimal ownership adjustment on the capital market, yields a negative relation between governance strictness and $\beta$, very much in the spirit of classic theories of levered beta: the stricter is governance, the less the manager can divert, the larger is the pie to distribute to shareholders, and thus the smaller $\beta$ (which is a per unit measure). But in full equilibrium, taking the manager's choice of ownership stake into account, this effect is reversed: we predict the quality of corporate governance to correlate positively both with $\beta$ and with idiosyncratic risk. The reason is that as long as effort is not just a scale factor but is able to improve the trade off between the variability of cash flows and their average, the value of the firm is larger but the risk does not change. Thus as governance worsens the unit of risk (systematic and idiosyncratic) for each dollar invested is lower.

These predictions are strongly confirmed in our empirical analysis. Our model also makes predictions about the relationship between the variables just discussed, and book value measures of returns, such as ROA, and managerial ownership. While we can confirm the prediction about returns on assets with our data, too, the test of our predictions about ownership is quite difficult because we do not have sufficiently good ownership data. A comprehensive answer is left for further research. 


\section{Appendix A: Proof of Proposition 5}

Throughout the formulas, we drop the subscript $i$.

\section{A Comparative statics of $g_{i}$}

Remember that $g_{i}$ is given by the first-order condition (27):

$$
r t^{2}\left(2 L+t g^{r}\right)=2 h\left(L+t g^{r}\right)^{2} g^{1-2 r}
$$

1. Letting $c=2 h / r t^{2}$ and differentiating (27) with respect to $L_{i}$ yields

$$
r t g^{r-1} \frac{d g}{d L}+2=c(1-2 r)\left(t g^{r}+L\right)^{2} g^{-2 r} \frac{d g}{d L}+2 c g^{1-2 r}\left(t g^{r}+L\right)\left(t r g^{r-1} \frac{d g}{d L}+1\right) .
$$

After rearranging, multiplying by $g^{1-r}\left(t g^{r}+L\right)$, and using (27) on both sides, this is equivalent to

$$
-2 L g^{1-r}=\left[3 r t L+r t^{2}+(1-2 r)\left(2 L+t g^{r}\right)\left(L g^{-r}+t\right)\right] \frac{d g}{d L}
$$

Hence, $\frac{d g}{d L}<0$ under the maintained assumption that $r \leq 1 / 2$.

2. Differentiating (27) and rearranging yields

$$
-\left(t g^{r}+L\right)^{2} g^{2-2 r}=\left[2 h\left(L+t g^{r}\right) r t g^{1-r}+h(1-2 r)\left(L+t g^{r}\right)^{2} g^{1-2 r}-\frac{r^{2} t^{3}}{2} g^{r}\right] \frac{d g}{d h}
$$

Using (27) and re-arranging as in 1. above shows that the squared bracket is strictly positive, hence $\frac{d g}{d h}<0$.

3. Differentiating (27) with respect to $t$ and rearranging along the lines sketched above yields $\frac{d g}{d t}>0$ as claimed in the proposition.

\section{B Comparative statics of $\beta_{i}$}

Remember that $\beta_{i}$ is given by (16), which in equilibrium (using (6) and (23)) reads

$$
\begin{aligned}
\beta & =\frac{B\left(1+R_{f}\right)}{F+\theta e-h g} \\
& =\frac{B\left(1+R_{f}\right)\left(L+t g^{r}\right)}{t^{2} g^{2 r}+(F-h g)\left(L+t g^{r}\right)} .
\end{aligned}
$$


1. Hence, $d \beta / d L>0$ iff

$$
\frac{d}{d L}\left(\frac{t^{2} g^{2 r}}{t g^{r}+L}-h g\right)<0
$$

We have

$$
\begin{aligned}
& \frac{d}{d L}\left(\frac{t^{2} g^{2 r}}{t g^{r}+L}-h g\right) \\
= & t^{2}\left[\frac{2 r g^{2 r-1} \frac{d g}{d L}\left(t g^{r}+L\right)-g^{2 r}\left(r t g^{r-1} \frac{d g}{d L}+1\right)}{\left(t g^{r}+L\right)^{2}}\right]-h \frac{d g}{d L} \\
= & t^{2}\left[\frac{\frac{d g}{d L}\left[r t g^{3 r-1}+2 r g^{2 r-1} L\right]-g^{2 r}}{\left(t g^{r}+L\right)^{2}}\right]-h \frac{d g}{d L} \\
< & 0
\end{aligned}
$$

where the last inequality follows by solving out for $h$ from (27) and rearranging.

2. We have

$$
\begin{aligned}
& \frac{d}{d h}\left(\frac{t^{2} g^{2 r}}{t g^{r}+L}-h g\right) \\
= & \frac{\left(2 r t^{2} g^{2 r-1} \frac{d g}{d h}\right)\left(t g^{r}+L\right)-t^{2} g^{2 r} r t g^{r-1} \frac{d g}{d h}}{\left(t g^{r}+L\right)^{2}}-h \frac{d g}{d h}-g
\end{aligned}
$$

Hence, a sufficient condition for $d \beta / d h>0$ is

$$
r t^{3} g^{3 r-1}+2 r t^{2} g^{2 r-1} L-h\left(t g^{r}+L\right)^{2}>0
$$

which again follows by solving out for $h$ from (27) and rearranging.

3. Similarly, $d \beta / d t<0$ iff

$$
\frac{d}{d t}\left(\frac{t^{2} g^{2 r}}{t g^{r}+L}-h g\right)>0 .
$$

We have

$$
\begin{aligned}
& \frac{d}{d t}\left(\frac{t^{2} g^{2 r}}{t g^{r}+L}-h g\right) \\
= & \frac{\left(2 t g^{2 r}+2 r t^{2} g^{2 r-1} \frac{d g}{d t}\right)\left(t g^{r}+L\right)-g^{3 r} t^{2}-t^{3} r g^{3 r-1} \frac{d g}{d t}}{\left(t g^{r}+L\right)^{2}}-h \frac{d g}{d t} .
\end{aligned}
$$


This has the same sign as

$$
t^{2} g^{3 r}+2 t g^{2 r} L+\left[r t^{3} g^{3 r-1}+2 r t^{2} g^{2 r-1} L-h\left(t g^{r}+L\right)^{2}\right] \frac{d g}{d t}
$$

Since $\frac{d g}{d t}>0$, the claim follows from (31). 


\section{Appendix B: The GIM Index}

The "Governance Index" introduced by Gompers, Ishii, and Metrick (2003) is a proxy for the level of shareholder protection in a company. It has been computed for about 1500 U.S. firms, covering more than $93 \%$ of the total capitalization of the NYSE, AMEX and NASDAQ, in 1990, 1993, 1995, 1998, 2000, 2002, 2004 and 2006. This index is based on 24 corporate-governance provisions. It is computed as the number of provisions, among these 24 provisions, which reduce shareholder's rights. So, the index ranges from 0 to 24 and, the higher is the index, the weaker are the shareholder's rights. 22 of these provisions are provided by the Investor Responsibility Research Center (IRRC). 6 other provisions are instituted by state law, among which 4 are redundant with the IRRC provisions. However, not all the U.S. states have adopted these 6 provisions. So, in case of redundancy of two provisions, they count only for one. Thus, the index in made of 24 provisions. The list of the provisions, along with a short description, is provided below. The provisions are clustered in five functional groups: Delay: tactics for delaying hostile bidders; Voting: shareholder's rights in elections or charter/bylaw amendments; Protection: protection for director/officer against job-related liability, and compensations; Other: other anti-takeover provisions; and State: state laws.

Some provisions may vary in amplitude: for instance, the supermajority threshold can vary from $51 \%$ to $100 \%$; however, no distinction is made; only the presence of such provision is considered. Also notice that even though some provisions might have a positive effect for shareholders in certain circumstances, as long as they increase management's power they are considered as weakening the shareholder's protection. The Secret ballot and the Cumulative voting provisions are the only ones increasing the shareholder's rights and their absence increases the index by one point each. Finally it is interesting to note that the index has no obvious industry concentration.

The detailed list of provisions is as follows:

- Delay: tactics for delaying hostile bidders

- Blank check: the issuance of preferred stocks, which give additional rights to its owner, to friendly investors is used as a "delay" strategy. 
- Classified board: the directors are placed into different classes and serve overlapping terms.

- Special meeting: it increases the level of shareholder support required to call special meetings

- Written consent: it limits actions beyond state law requirement

- Voting: shareholder's rights in elections or charter/bylaw amendments

- Compensation plans: it enables participants in incentive bonus plans to cash out options or accelerate the payout of bonuses in case of change in control.

- Contracts: contracts between the company and some directors/officers indemnifying them from legal expenses and judgments resulting from lawsuits. The contracts comes in addition to indemnification.

- Golden parachutes: severance agreements that provides a compensation to senior executives upon an event such as termination, resignation, etc.

- Indemnification: it uses bylaws and/or charters to indemnify directors/officers from legal expenses and judgment. The contracts comes in addition.

- Liability: it is a limitation on director personal liability to the extent allowed by state law.

- Protection: protection for director/officer against job-related liability, and compensations

- Bylaws: it limits the shareholder's ability to amend the governing documents of a company through bylaws.

- Charter: it limits the shareholder's ability to amend the governing documents of a company through charter.

- Cumulative voting: it allows a shareholder to allocate his total votes in any manner desired.

- Secret ballot: an independent third party counts votes and the management agrees not to look at individual votes 
- Supermajority: it increases the level of the majority, with respect to the state law requirement, required to approve a merger

- Unequal voting: it limits the voting rights of some shareholders and expands those of others.

- Other: other anti-takeover provisions

- Anti-greenmail: it discourages agreements between a shareholder and a company whose aim is the accumulation of large quantities of stocks.

- Director's duties: it allows a director to consider constituencies other than shareholders, i.e. employees, suppliers, etc., when considering a merger.

- Fair price: it limits the range of prices a bidder can pay in two-tier offers.

- Pension parachutes: it prevents an acquirer from using surplus cash in the pension fund of the company

- Poison pill: it provides special rights to their holders in case of specific events such as a hostile takeover. Such rights are made to render the target unattractive.

- Silver parachutes: similar to golden parachutes except that it is extent to a large number of employees

- State: state laws

- Anti-greenmail law (7 U.S. states)

- Business combination law: imposes a moratorium on certain transactions between a large shareholder and a company (27 U.S. states)

- Cash-out law: enables shareholders to sell their stake to a controlling shareholder at a certain price (3 U.S. states)

- Directors' duties law

- Fair price law

- Control share acquisition law: see supermajority 


\section{References}

Acharya, V., O. Gottschalg, M. Hahn and C. Kehoe, (2011), "Corporate Governance and Value Creation: Evidence from Private Equity", NYU Working Paper No. FIN-08032 .

Anderson R. and S. Lee, (1997), "Ownership studies: the data source does matter", The Journal of Financial and Quantitative Analysis, 32, 3, 311-329.

Bebchuk, L., A. Cohen, and A. Ferrell, (2009), "What Matters in Corporate Governance?", Review of Financial Studies, 22, 2, 783-827.

Bebchuk, L., A. Cohen, and C.C.Y. Wang, (2013), "Learning and the Disappearing Association Between Governance and Returns", Journal of Financial Economics, forthcoming.

Bebchuk, L. and M. Weisbach (2010), "The State of Corporate Governance Research", Review of Financial Studies 23, 939-961.

Bound, J., D. A. Jaeger, and R. M. Baker, (1995), "Problems with instrumental variables estimation when the correlation between the instruments and the endogenous explanatory variable is weak", Journal of the American Statistical Association, 90, 443-450.

Burkhart, M., D. Gromb, and F. Panunzi, (1997), "Large Shareholders, Monitoring, and the Value of the Firm", Quarterly Journal of Economics,112, 693-728.

Cella, C., A. Ellul, and M. Giannetti, (2013), "Investors' horizons and the Amplification of Market Shocks," Review of Financial Studies, forthcoming.

Cremers, K.J.M. and V.B. Nair, (2005), "Governance Mechanisms and Equity Prices", Journal of Finance, 60, 6, 2859-2894.

Cremers, K.J.M., V.B. Nair, and K. John, (2009), "Takeovers and the Cross-Section of Returns", Review of Financial Studies, 22, 4, 1409-1445.

Dlugosz, J., R. Fahlenbrach, P. Gompers, and A. Metrick, (2006), "Large Blocks of Stock: Prevalence, Size, and Measurement", Journal of Corporate Finance, 12, 594-618. 
Durnev, A., R. Morck, and B. Yeung, (2004), "Value-enhancing capital budgeting and firm-specific stock return variation", Journal of Finance, 59, 65-105.

Durnev, A., R. Morck, B. Yeung, and P. Zarowin, (2003), "Does greater firm-specific return variation mean more or less informed stock pricing?", Journal of Accounting Research, 41, 797-836.

Easley, D. and M. O'Hara, (2004), "Information and the Cost of Capital", Journal of Finance, 59, 1553-1583.

Falk, A. and M. Kosfeld, (2006) "The Hidden Costs of Control," American Economic Review, 96, 5, 1611-1630.

Ferreira, M. and P. Laux, (2007), "Corporate Governance, Idiosyncratic Risk, and Information Flow", Journal of Finance, 62, 951-989.

Giannetti M. and Y. Koskinen, (2010), "Investor Protection, Equity Returns and Financial Globalization", Journal of Financial and Quantitative Analysis, 45, 1, 135-168.

Gompers, P., J. Ishii, and A. Metrick, (2003), "Corporate Governance and Equity Prices", Quarterly Journal of Economics, 118, 107-155.

Hamada, R.S., (1972), “The Effect of the Firm's Capital Structure on the Systematic Risk of Common Stock", Journal of Finance 27, 435-452.

Harris, M. and A. Raviv, (2010), "Control of Corporate Decisions: Shareholders vs. Management", Review of Financial Studies, 23, 11, 4115-47.

Hellwig, M. F., (2000), "On the Economics and Politics of Corporate Finance and Corporate Control," in Vives, X. (Ed.), "Corporate Governance, Theoretical and Empirical Perspectives", Cambridge University Press 95-134.

Jin, L. and S.C. Myers, (2006), "R ${ }^{2}$ around the world: new theory and new tests" Journal of Financial Economics, 25, 257-292.

Johnson S., T. Moorman, and S. M. Sorescu, (2009), "A Reexamination of Corporate Governance and Equity Prices", Review of Financial Studies 22, 11, 4753-4786. 
Lambert, R.A., C. Leuz, and R. Verrecchia, (2009), "Information Asymmetry, Information Precision, and the Cost of Capital" NBER Working Paper No. 14881, April.

Modigliani, F. and M. Miller, (1958), "The Cost of Capital, Corporation Finance, and the Theory of Investment", American Economic Review, 48, 261-297.

Morck, R., B. Yeung, and W. Yu, (2000), "The information content of stock markets: why do emerging markets have synchronous stock price movements?", Journal of Financial Economics, 58, 215-260.

Sautner, Z. and B. Villalonga, (2011), "Corporate Governance and Internal Capital Markets", Harvard Business School Finance Working Paper No. 1530565.

Shleifer, A. and Vishny, R. W., (1997), "A Survey of Corporate Governance", Journal of Finance, 52, 737-783.

Vives, X., (2000), "Corporate Governance: Does It Matter?" in Vives., X. (Ed.), "Corporate Governance, Theoretical and Empirical Perspectives", Cambridge University Press, 1-22.

von Lilienfeld-Toal, U. and S. Ruenzi, (2012), "CEO Ownership and Stock Market Performance, and Managerial Discretion" mimeo, University of Mannheim

Zingales, L., (2008), "Corporate Governance" in Durlauf, S.N. and L.E. Blume (Eds.), "The New Palgrave Dictionary of Economics". Second Edition. Macmillan, London. 


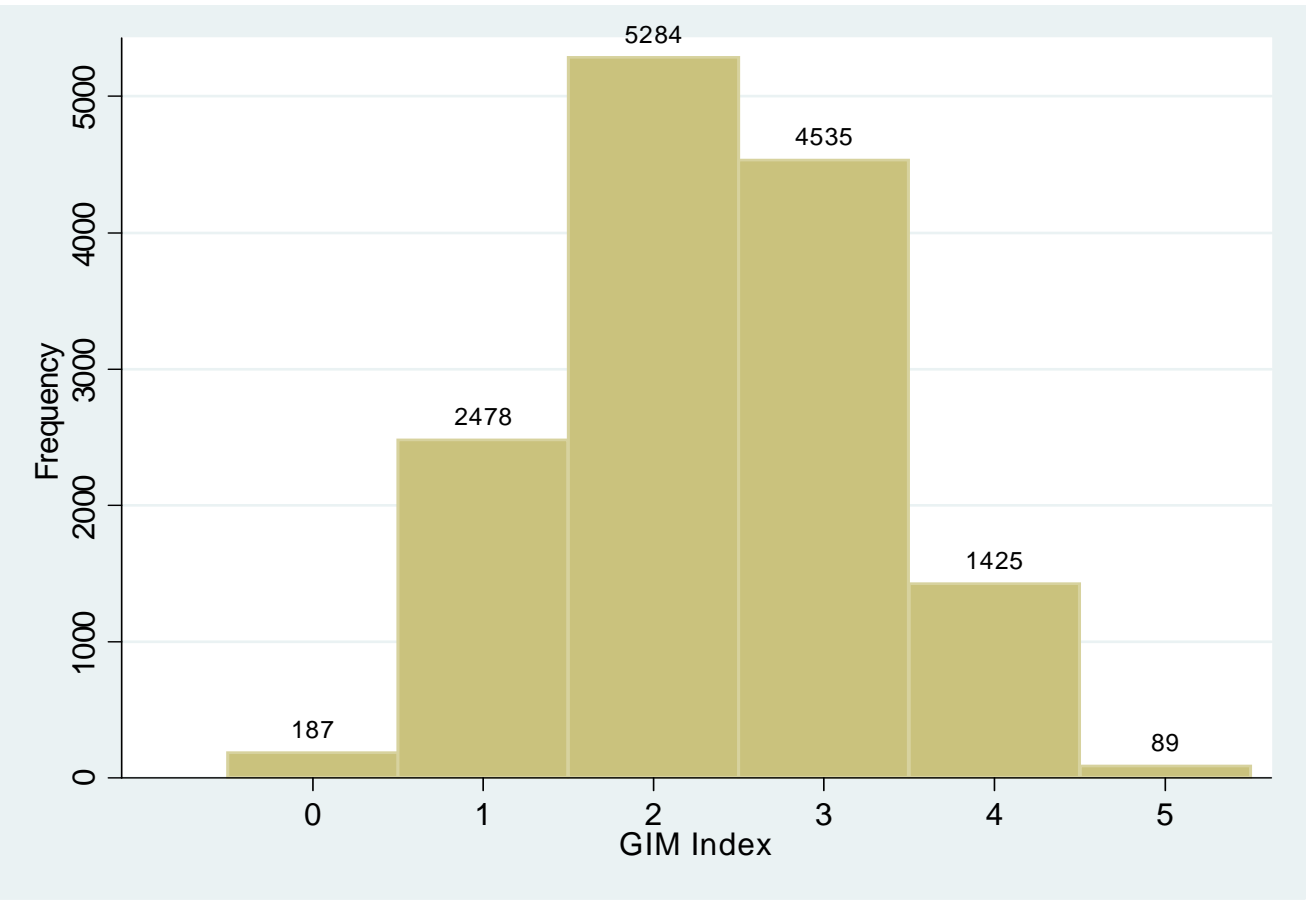

Figure 1: Distribution of the GIM Index

Table I: Transition matrix of the GIM Index

\begin{tabular}{c|cccccc}
\hline \hline $\mathrm{t} \backslash \mathrm{t}+1$ & 0 & 1 & 2 & 3 & 4 & 5 \\
\hline 0 & 70 & 48 & 9 & 0 & 0 & 0 \\
1 & 13 & 1,244 & 381 & 23 & 5 & 0 \\
2 & 0 & 89 & 2,912 & 463 & 16 & 0 \\
3 & 1 & 5 & 178 & 2,764 & 175 & 0 \\
4 & 0 & 3 & 8 & 110 & 926 & 17 \\
5 & 0 & 0 & 0 & 0 & 9 & 57 \\
\hline This table describes the number of firms that \\
reports a certain level of the GIM Index at time \\
$\mathrm{t}$ (Rows) and the same or another GIM index at \\
time t+1 (Columns). Higher GIM Index indicates \\
worse governance. The sample period is from \\
1990 to 2006. Number of observations 13,004. \\
\hline \hline
\end{tabular}


Table II: Variables description

\begin{tabular}{|c|c|c|}
\hline VARIABLE & DEFINITION & SOURCE \\
\hline Idios. Vol. & $\begin{array}{c}\text { Annualized daily variance estimated } \\
\text { from market model }\end{array}$ & Elab. on CRSP data \\
\hline Market vol. & $\begin{array}{l}\text { Annualized daily standard devisation of the market portfolio } \\
\text { (value weighted index of stocks in our dataset) }\end{array}$ & Elab. on CRSP data \\
\hline sqrVR & $\begin{array}{l}\text { Normalized idiosyncrratic volatility given by } \\
\text { the ratio of Idiosyncratic volatility to Market volatility }\end{array}$ & Elab. on CRSP data \\
\hline Beta & Yearly Beta of asset $\mathrm{i}$ & Elab. on CRSP data \\
\hline EPS & Earnings Per Share (Basic) - Excluding Extraordinary Items & S\&P Compustat \\
\hline ROA & $\begin{array}{c}\text { Return on Asset defined as the ratio } \\
\text { of Earnings to Total Assets }\end{array}$ & $\begin{array}{l}\text { Elab. on S\&P } \\
\text { Compustat data }\end{array}$ \\
\hline LEV & $\begin{array}{l}\text { Leverage defined as the ratio of } \\
\text { long term debt to total assets }\end{array}$ & $\begin{array}{l}\text { Elab. on S\&P } \\
\text { Compustat data }\end{array}$ \\
\hline MKTV & $\begin{array}{l}\text { Market Value defined as the Annual Fiscal Price } \\
\text { Close multiplied by Common Shares Outstanding }\end{array}$ & $\begin{array}{l}\text { Elab. on S\&P } \\
\text { Compustat data }\end{array}$ \\
\hline PTBV & $\begin{array}{l}\text { Price to Book Value defined as the Annual Fiscal Price } \\
\text { Close multiplied by the Book Value per Share }\end{array}$ & $\begin{array}{l}\text { Elab. on S\&P } \\
\text { Compustat data }\end{array}$ \\
\hline DY & $\begin{array}{c}\text { Dividend Yield defined by the ratio of Total } \\
\text { dividends to Market Value }\end{array}$ & $\begin{array}{l}\text { Elab. on S\&P } \\
\text { Compustat data }\end{array}$ \\
\hline AGE & $\begin{array}{l}\text { Number of years between the year of observation } \\
\text { and the year of stock inclusion in the CRSP database }\end{array}$ & $\begin{array}{l}\text { Elab. on S\&P } \\
\text { Compustat data }\end{array}$ \\
\hline
\end{tabular}

This Table reports the description of the variables used in the analysis and the source of these variables. 
Table III: Univariate Analysis

\begin{tabular}{|c|c|c|c|c|c|c|c|c|c|}
\hline & N.obs & Beta & sqrtVR & MKTV & $\overline{D Y}$ & $\overline{\text { PTBV }}$ & LEV & ROA & AGE \\
\hline All g's & 24,789 & 0.952 & 2.657 & 5000 & 0.019 & 2.725 & 0.200 & 0.032 & 24.346 \\
\hline$s d$ & & 0.542 & 1.428 & 11884 & 0.023 & 2.920 & 0.171 & 0.091 & 18.213 \\
\hline $\mathrm{g}=0,1,2$ & 13,420 & 0.993 & 2.813 & 5123 & 0.016 & 2.777 & 0.195 & 0.030 & 20.818 \\
\hline$s d$ & & 0.577 & 1.486 & 12992 & 0.023 & 2.995 & 0.181 & 0.100 & 17.234 \\
\hline $\mathrm{g}=3,4,5$ & 11,369 & 0.904 & 2.473 & 4856 & 0.021 & 2.664 & 0.205 & 0.034 & 28.509 \\
\hline$s d$ & & 0.493 & 1.333 & 10424 & 0.021 & 2.827 & 0.158 & 0.078 & 18.457 \\
\hline $\mathrm{g}=\mathbf{0}$ & 271 & 0.912 & 3.130 & 4131 & 0.018 & 2.212 & 0.177 & 0.013 & 17.646 \\
\hline$s d$ & & 0.660 & 1.795 & 11943 & 0.024 & 2.556 & 0.182 & 0.109 & 14.763 \\
\hline$g=1$ & 4074 & 0.995 & 2.900 & 5417 & 0.015 & 2.845 & 0.186 & 0.035 & 18.342 \\
\hline$s d$ & & 0.596 & 1.534 & 14233 & 0.023 & 2.989 & 0.191 & 0.099 & 15.999 \\
\hline$g=2$ & 9075 & 0.995 & 2.764 & 5020 & 0.017 & 2.763 & 0.200 & 0.028 & 22.025 \\
\hline$s d$ & & 0.565 & 1.451 & 12424 & 0.024 & 3.008 & 0.177 & 0.099 & 17.702 \\
\hline$g=3$ & 8,439 & 0.914 & 2.512 & 4935 & 0.021 & 2.713 & 0.205 & 0.033 & 27.395 \\
\hline$s d$ & & 0.506 & 1.372 & 10657 & 0.022 & 2.963 & 0.162 & 0.084 & 18.609 \\
\hline $\mathrm{g}=4$ & 2,760 & 0.882 & 2.364 & 4736 & 0.023 & 2.540 & 0.204 & 0.036 & 31.784 \\
\hline$s d$ & & 0.452 & 1.213 & 9910 & 0.019 & 2.432 & 0.144 & 0.061 & 17.705 \\
\hline$g=5$ & 170 & 0.763 & 2.279 & 2877 & 0.021 & 2.212 & 0.194 & 0.035 & 30.653 \\
\hline$s d$ & & 0.479 & 1.170 & 5558 & 0.022 & 1.472 & 0.149 & 0.059 & 16.274 \\
\hline two means & t-test & 12.876 & 18.819 & 1.761 & -16.907 & 3.038 & -4.382 & -3.704 & -33.887 \\
\hline
\end{tabular}

This table reports the mean, the standard deviation and the number of observations of the variables. All variables are as defined in Table II. The sample period is from 1990 to 2006. All variables are winsorized at the bottom and top $1 \%$ levels. Univariate statistics are reported for all the sample and according to the GIM index. In the bottom row we present the two-mean test of the statistical difference of the variables between companies with better governance (GIM Index 0,1,2) and companies with worse governance (GIM Index $3,4,5)$. 
Table IV: Correlations

\begin{tabular}{ccccccccc}
\hline \hline & GIM & Beta & sqrtVR & LNAGE & LNMV & DY & PTBV & LEV \\
\hline Beta & -0.0737 & & & & & & & \\
sqrtVR & -0.1277 & 0.3237 & & & & & & \\
LNAGE & 0.2546 & -0.1792 & -0.2506 & & & & & \\
LNMV & 0.0790 & 0.1307 & -0.4727 & 0.2218 & & & & \\
DY & 0.1111 & -0.2972 & -0.1885 & 0.3144 & -0.0301 & & & \\
PTBV & -0.0223 & 0.1179 & -0.0644 & -0.0260 & 0.3335 & -0.1633 & & \\
LEV & 0.0344 & -0.1274 & 0.0088 & 0.0285 & -0.0609 & 0.1279 & -0.0700 & \\
ROA & 0.0177 & -0.0822 & -0.3311 & 0.1113 & 0.3184 & -0.0454 & 0.2337 & -0.1908 \\
\hline \hline
\end{tabular}

This table presents correlations between the variables we use in the analysis. The sample period is from 1990 to 2006 . All values are significant at $1 \%$ level. The number of observations is 24,789 . All variables are winsorized at the bottom and top $1 \%$ levels. 
Table V: Two-stage Regression. Instrumental variable: Age

\begin{tabular}{cccc}
\hline \hline & 1-st stage & 2-nd stage & 2-nd stage \\
\hline & GIM Index $\left(g_{i, t}\right)$ & Beta $\left(\beta_{i, t}\right)$ & sqrtVR $\left(\frac{\sigma_{\eta}, t}{\sigma,}\right)$ \\
\hline GIM instrumented $\left(\widehat{g}_{i, t}\right)$ & & $-0.275^{* * *}$ & $-0.691^{* * *}$ \\
LNMV & $0.0263^{* *}$ & $(-7.882)$ & $-(-9.317)$ \\
LEV & $(1.965)$ & $(12.27)$ & $(-22.08)$ \\
& 0.0917 & -0.0315 & $0.221^{* *}$ \\
ROA & $(1.056)$ & $(-0.747)$ & $(2.293)$ \\
& $-0.204^{*}$ & $-0.747^{* * *}$ & $-3.891^{* * *}$ \\
PTBV & $(-1.660)$ & $(-10.29)$ & $(-24.35)$ \\
& $-0.00645^{*}$ & $0.00735^{* * *}$ & $0.0277^{* * *}$ \\
LNAGE & $(-1.653)$ & $(3.385)$ & $(6.042)$ \\
& $0.259^{* * *}$ & & \\
Constant & $(12.60)$ & & \\
& $1.299^{* * *}$ & $0.909^{* * *}$ & $5.324^{* * *}$ \\
Sector dummies & $(9.548)$ & $(10.56)$ & $(29.64)$ \\
Years dummies & Yes & Yes & Yes \\
& Yes & Yes & Yes \\
N_obs & & & \\
N_cluster & 24,789 & 24,789 & 24,789 \\
Kleibergen-Paap test Chi-sq(1) p-value & 3,453 & 3,453 & 3,453 \\
Kleibergen-Paap Wald F statistic & & 0.000 & 0.000 \\
\hline \hline
\end{tabular}

This table presents the estimation results of the two-stage least squares instrumental variable panel regression of the relationship between the GIM Index $\left(g_{i, t}\right)$ and respectively beta $\left(\beta_{i, t}\right)$ and idiosyncratic risk $\left(s q r t V R_{i}\right)$. 1st-stage column reports the first stage regression $(28)$ :

$$
g_{i, t}=a+a_{j} D_{j}+a_{t} D_{t}+\underline{\phi_{1}} \underline{X_{1}}+\underline{\phi_{2}} \underline{X_{2}}+\epsilon_{i, t}
$$

where $\underline{X_{1}}$ and $\underline{X_{2}}$ are two sets of exogenous variables; $\epsilon_{i, t}$ is the error terms, $a$ is the constant; $D_{i}$ are industry dummies, $D_{t}$ are time dummies, $a_{j}, \alpha_{t}$ are dummy coefficients; and $\underline{\phi_{1}}$ and $\underline{\phi_{2}}$ are vectors of coefficients. We also report the estimation results for the second-stage regressions $(29)$

$$
\begin{gathered}
s q r t V R_{i}=b+b_{j} D_{j}+b_{t} D_{t}+\beta_{1} \widehat{g}_{i, t}+\underline{\theta_{1} X_{1}}+\nu_{i, t}, \\
\beta_{i, t}=c+c_{j} D_{j}+c_{t} D_{t}+\gamma_{1} \widehat{g}_{i, t}+\underline{\vartheta_{1} X_{1}}+v_{i, t},
\end{gathered}
$$

where where $\widehat{g}_{i, t}$ is the fitted values of $g_{i, t}$ from the first-stage regression, $\nu_{i, t}$ and $v_{i, t}$ are the error terms, $b$ and $c$ are the constant; $b_{j}, c_{j}, b_{t}, c_{t}, \beta_{1}$, and $\gamma_{1}$ are coefficients; and $\underline{\theta_{1}}$ and $\underline{\vartheta_{1}}$ are vectors of coefficients. The dependent variables are the return risk measures: factor loading to market portfolio $\beta_{i, t}$, ie. BETA (Yearly Beta of asset $i$ ) and idiosyncratic risk sqrtV $R_{i}$, i.e. the normalized idiosyncratic volatility given by the ratio of idiosyncratic volatility to market volatility. Explanatory variables are as defined in Table II. The instrumental variable is LNAGE. Regressions are based on yearly data and t-statistics are calculated using standard errors that are clustered at firm level. The sample period is 1990-2006. All variables are winsorized at the bottom and top $1 \%$ levels. *** Coefficients significant at the $1 \%$ level, $* *$ Coefficients significant at the $5 \%$ level, * Coefficients significant at the $10 \%$ level, 
Table VI: Two-stage Regression. Instrumental variable: Dividend Yield

\begin{tabular}{|c|c|c|c|}
\hline & 1-st stage & 2-nd stage & 2-nd stage \\
\hline & GIM Index $\left(g_{i, t}\right)$ & $\operatorname{Beta}\left(\beta_{i, t}\right)$ & $\operatorname{sqrtVR}\left(\frac{{ }^{o} \eta_{i, t}}{\sigma_{M}}\right)$ \\
\hline GIM instrumented $\left(\widehat{g}_{i, t}\right)$ & & $\begin{array}{c}-0.914^{* *} \\
(-5.456)\end{array}$ & $\begin{array}{c}-2.003^{* *} \\
(-5.480)\end{array}$ \\
\hline LNMV & $\begin{array}{c}0.0637^{* * *} \\
(4.855)\end{array}$ & $\begin{array}{c}0.112^{* * *} \\
(6.820)\end{array}$ & $\begin{array}{c}-0.203^{* * *} \\
(-5.756)\end{array}$ \\
\hline LEV & $\begin{array}{l}0.0145 \\
(0.162)\end{array}$ & $\begin{array}{l}-0.0129 \\
(-0.145)\end{array}$ & $\begin{array}{c}0.259 \\
(1.358)\end{array}$ \\
\hline $\mathrm{ROA}$ & $\begin{array}{c}-0.169 \\
(-1.349)\end{array}$ & $\begin{array}{c}-0.885^{* * *} \\
(-6.604)\end{array}$ & $\begin{array}{c}-4.173^{* * *} \\
(-14.30)\end{array}$ \\
\hline PTBV & $\begin{array}{c}-0.0101^{* *} \\
(-2.501)\end{array}$ & $\begin{array}{l}-9.58 \mathrm{e}-05 \\
(-0.0214)\end{array}$ & $\begin{array}{l}0.0125 \\
(1.299)\end{array}$ \\
\hline DY & $\begin{array}{c}4.251^{* * *} \\
(5.815)\end{array}$ & & \\
\hline Constant & $\begin{array}{c}1.761^{* * *} \\
(13.93)\end{array}$ & $\begin{array}{c}2.152^{* * *} \\
(6.202)\end{array}$ & $\begin{array}{c}7.876^{* * *} \\
(10.50)\end{array}$ \\
\hline Sector dummies & Yes & Yes & Yes \\
\hline Years dummies & Yes & Yes & Yes \\
\hline N_obs & 24,789 & 24,789 & 24,789 \\
\hline N_cluster & 3,453 & 3,453 & 3,453 \\
\hline Kleibergen-Paap test Chi-sq(1) p-value & & 0.000 & 0.000 \\
\hline Kleibergen-Paap Wald F statistic & & 33.814 & 33.814 \\
\hline
\end{tabular}

This table presents the estimation results of the two-stage least squares instrumental variable panel regression of the relationship between the GIM Index $\left(g_{i, t}\right)$ and respectively beta $\left(\beta_{i, t}\right)$ and idiosyncratic risk $\left(s q r t V R_{i}\right)$. 1st-stage column reports the first stage regression $(28)$ :

$$
g_{i, t}=a+a_{j} D_{j}+a a D_{t}+\underline{\phi_{1}} \underline{X_{1}}+\underline{\phi_{2}} \underline{X_{2}}+\epsilon_{i, t}
$$

where $X_{1}$ and $X_{2}$ are two sets of exogenous variables; $\epsilon_{i, t}$ is the error terms, $a$ is the constant; $D_{i}$ are industry dummies, $D_{t}$ are time dummies, $a_{j}, a_{t}$ are dummy coefficients; and $\underline{\phi_{1}}$ and $\underline{\phi_{2}}$ are vectors of coefficients. We also report the estimation results for the second-stage regressions $(29)$,

$$
\begin{gathered}
\operatorname{sqrtV} R_{i}=b+b_{j} D_{j}+b_{t} D_{t}+\beta_{1} \widehat{g}_{i, t}+\underline{\theta_{1} X_{1}}+\nu_{i, t}, \\
\beta_{i, t}=c+c_{j} D_{j}+c_{t} D_{t}+\gamma_{1} \widehat{g}_{i, t}+\underline{\vartheta_{1} X_{1}}+v_{i, t},
\end{gathered}
$$

where where $\widehat{g}_{i, t}$ is the fitted values of $g_{i, t}$ from the first-stage regression, $\nu_{i, t}$ and $v_{i, t}$ are the error terms, $b$ and $c$ are the constant; $b_{j}, c_{j}, b_{t}, c_{t}, \beta_{1}$, and $\gamma_{1}$ are coefficients; and $\underline{\theta_{1}}$ and $\underline{\vartheta_{1}}$ are vectors of coefficients. The dependent variables are the return risk measures: factor loading to market portfolio $\beta_{i, t}$, ie. BETA (Yearly Beta of asset $i$ ) and idiosyncratic risk $\operatorname{sqr} t V R_{i}$, i.e. the normalized idiosyncratic volatility given by the ratio of idiosyncratic volatility to market volatility. Explanatory variables are as defined in Table II. The instrumental variable is DY (Dividend Yield). Regressions are based on yearly data and t-statistics are calculated using standard errors that are clustered at firm level. The sample period is 1990-2006. All variables are winsorized at the bottom and top $1 \%$ levels. $* * *$ Coefficients significant at the $1 \%$ level, ** Coefficients significant at the $5 \%$ level, * Coefficients significant at the $10 \%$ level, 